I N S T I T U T O

$\mathrm{DE}$

M E D I C I N A

T R O P I C A L

DE

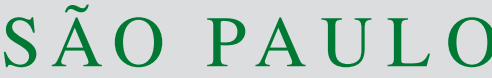

JOURNAL OF THE SÃO PAULO INSTITUTE OF TROPICAL MEDICINE

${ }^{1}$ Universidade do Estado do Rio de Janeiro, Instituto de Medicina Social, Departamento de Política, Planejamento e Administração em Saúde, Rio de Janeiro, Rio de Janeiro, Brazil

2Universidade Federal Fluminense, Instituto de Saúde Coletiva, Departamento de

Saúde e Sociedade, Niterói, Rio de Janeiro, Brazil

Correspondence to: Cid Manso de Mello Vianna

Universidade do Estado do Rio de Janeiro, Instituto de Medicina Social, Departamento de Política, Planejamento e Administração em Saúde, Rua São Francisco Xavier 524, Maracanã, Bloco D, 7ํandar, CEP 20550013, Vila Isabel, Rio de Janeiro, RJ, Brazil Tel: +55 $212334-0235$

E-mail: cdvianna@gmail.com

Received: 8 April 2021

Accepted: 20 June 2021

\section{Cost-effectiveness analysis and budgetary impact of the Cryptococcal Antigen Lateral Flow Assay (CRAG-LFA) implementation for the screening and diagnosis of cryptococcosis in asymptomatic people living with HIV in Brazil}

\author{
Cid Manso de Mello Vianna ${ }^{\circledR}$, Gabriela Bittencourt Gonzalez Mosegui ${ }^{\circledR}$
}

\section{ABSTRACT}

Cryptococcal infection is a frequent cause of mortality in Brazilian HIV-infected patients. The present study aimed to evaluate the cost-effectiveness and budgetary impact of four cryptococcosis screening strategies in HIV-infected patients with CD4+ $\leq 200$ cells $/ \mathrm{mm}^{3}$, in Brazil. A Monte Carlo microsimulation was used to compare the following diagnostic tests: a systematic serum cryptococcal antigen (CRAG) screening with latex agglutination (CRAG-LA), a lateral flow immunochromatographic test (CRAG-LFA), India ink staining and no intervention. The rationale was that of the Unified Health System (SUS), and the time horizon was of one year for the intervention and of five years for the budgetary impact analysis (BIA). The effectiveness outcomes were years of life and years of life adjusted for quality (QALY). The cost-effectiveness analysis showed that the two cryptococcal antigen tests were cost-effective, presenting with superior results in comparison with India ink and no screening. CRAG-LFA, compared to CRAG-LA, has an incremental cost of US $\$ 0.25$ and an incremental cost-effectiveness ratio of US\$73.36 (considering the US dollar equal to 5 reais, the Brazilian current money). The probabilistic sensitivity analysis between CRAG-LFA and CRAG-LA, despite showing a high agreement between the two tests, indicated the superiority of CRAG-LFA. The BIA estimated that the incorporation of CRAG-LFA would have an additional cost of approximately U\$S 10.4 million dollars in five years. These findings suggest that, for the group of studied patients, the adoption of CRAG-LFA and CRAG-LA are cost-effective, while the India ink test and no intervention are less effective strategies. The BIA showed that using the CRAG-LFA test for people living with HIV (PLHIV) with CD4+ $\leq 200$ cells $/ \mathrm{mm}^{3}$ could reduce costs for the Brazilian Unified Health System (SUS).

KEYWORDS: Cost-benefit analysis. Diagnostic test approval. Cryptococcus. HIV infections.

\section{INTRODUCTION}

Cryptococcosis is a systemic mycosis caused by fungi of the genus Cryptococcus. The infection typically affects the central nervous system (CNS) and the respiratory tract, commonly presenting as cryptococcal meningitis (CM). HIV infection with a CD4 count below 200 cells $/ \mathrm{mm}^{3}$ and the presence of the acquired immunodeficiency syndrome (AIDS) are predisposing conditions for cryptococcosis ${ }^{1}$.

CM is associated with about $15 \%$ of all HIV deaths. In 2014, a total of $223,100 \mathrm{CM}$ cases led to 181,100 deaths, $75 \%$ of which in sub-Saharan Africa, followed by Southeast Asia and Latin America ${ }^{2}$. In Brazil, the cryptococcosis mortality rate is between $45 \%$ to $65 \%$ regardless of HIV risk factors and the primary 
form of the disease ${ }^{3}$. Cryptococcosis occurs as the first opportunistic manifestation in about $4.4 \%$ of AIDS cases in Brazil $^{3,4}$. In addition, patients recovering from cryptococcal meningitis may experience long-term neurological and sensory impairment ( $\geq 3$ months after the diagnosis), resulting in disability and poor quality of life ${ }^{5,6}$ a tertiary referral hospital to HIV-infected patients serving the São Paulo State, Brazil. All patients were $>18$ years old without prior cryptococcal meningitis, without clinical suspicion of cryptococcal meningitis, regardless of antiretroviral (ART.

The Unified Health System (SUS) provides different methods for diagnosing Cryptococcosis. The conventional one is the direct examination of slides stained with India ink and the sample's culture on Sabouraud dextrose agar $(\mathrm{SDA})^{4}$. In the case of Cryptococcosis, the India ink method refers to the direct microscopy of the cerebrospinal fluid (CSF), secretions or exudates, subcutaneous aspirate, pus, urine, serum, plasma or blood to visualize yeasts ${ }^{4}$. In contrast, the SDA culture consists of yeast culture for seven days, between $25^{\circ} \mathrm{C}$ to $37^{\circ} \mathrm{C}^{4}$. Serological techniques can be used to detect antigens (CRAG) or search for antibodies. The latex agglutination test (CRAG-LA) is one of the most frequently used due to its high accuracy ${ }^{4,7}$ along with the lateral flow immunochromatographic test $(\mathrm{LFA})^{8}$ the cryptococcal antigen lateral flow assay $(\mathrm{CrAg}$ LFA. The CRAG-LFA is a rapid diagnostic test that provides a definitive result in $\leq 10 \mathrm{~min}$. with no need of specialized physical structure. The technique is stable at room temperature and easy to use and interpret results ${ }^{8}$ the cryptococcal antigen lateral flow assay (CrAg LFA.

The Brazilian Ministry of Health (MH) Clinical Protocol and Therapeutic Guideline (CPTG) for the treatment of adults with HIV recommends that people living with HIV (PLHIV) should to be investigated for fungal etiology in all pneumonia cases in addition to the routinely performed exams ${ }^{7}$. Those who are CRAG-positive and present with $\mathrm{CD} 4 \leq 100$ cells $/ \mathrm{mm}^{3}$ are subjected to preemptive treatment with fluconazole and antiretroviral therapy (ART) until they reach CD4 $>200$ cells $/ \mathrm{mm}^{3}$. The cost-effectiveness of CRAG screening, in either asymptomatic or symptomatic CM patients, has never been evaluated in Brazil.

The primary aim of this study was to model the costeffectiveness and budget impact of implementing CRAG screening for asymptomatic cryptococcus infections in PLHIV with CD4+ $\leq 200$ cells $/ \mathrm{mm}^{3}$, in Brazil.

\section{MATERIALS AND METHODS}

A Monte Carlo analytical decision model assessed the cost-effectiveness ratio and budgetary impact of the screening of PLHIV, over 18 years old, of both genders, infected with cryptococcosis, asymptomatic, with CD4 $\leq 200$ cells $/ \mathrm{mm}^{3}$, using the following methods as screening strategies: (a) the point-of-care diagnostic test CRAG-LFA, (b) cryptococcus research in CSF with India ink or (c) CRAG-LA in serum, using no intervention as the baseline. Each strategy has its own accuracy value and employs different sample collection methods. This type of analysis records the patient's history and the transition probabilities depend on the variables involved, allowing great clinical complexity in the development of the model.

The perspective adopted considered the SUS as the funding agency for the services. The horizon for the costeffectiveness analysis was one year for the intervention, evaluating its impact on the disease's development for five years, as many patients have life expectancies almost equal to those of people without $\mathrm{HIV}^{9}$. A discount rate of $3 \%$ per year was applied ${ }^{10}$.

The primary outcomes were years of life and qualityadjusted life years (QALY) ${ }^{2,11}$. Estimates referring to direct medical costs included the identification, measurement and evaluation of the applied resources. A sensitivity analysis ${ }^{10}$ assessed the uncertainties of the model.

According to the CPTG for the management of HIV infection in adults ${ }^{7}$, the screening and preemptive treatment strategy for cryptococcosis prevent deaths in individuals with ART CD4+ $\leq 100$ cells $/ \mathrm{mm}^{3}$. The document highlights patients without clinical manifestations of cryptococcosis but presenting with a test showing positive detection of cryptococcal antigenemia in CSF samples obtained by lumbar puncture (LP), performed to rule out CM. Then, a preemptive treatment with $800 \mathrm{mg}$ fluconazole per day for two weeks and $400 \mathrm{mg}$ fluconazole per day for eight weeks is prescribed and ART will be administered after the first two weeks of antifungal treatment ${ }^{4,7}$. All individuals with positive plasma or serum tests are investigated for CM using LP. The treatment of positive cases follow these phases: (a) induction, (b) consolidation and (c) maintenance, recommended by the Brazilian consensus and $\mathrm{CPTG}^{4,7}$.

SUS's reimbursement amounts for different items were used as measures of the abovementioned costs. Procedures and test values were obtained from the-Ministry of Health ${ }^{12-14}$ and, when not available, from the Brazilian Hierarchical Classification of Medical Procedures of the Brazilian Medical Association (BMA) ${ }^{15}$ in addition to several consultations of studies by Lofgren $\mathrm{et} \mathrm{al} .{ }^{16}$ implementation studies and evaluations of how to integrate $\mathrm{CrAg}$ screening programs into existing HIV care infrastructure are lacking. During a CrAg screening program in Kampala, Uganda, we interviewed 15 health care workers ( 2 coordinating research nurses and 13 clinic personnel and Rajasinghan et al. ${ }^{17}$ and $\mathrm{CrAg}$ positivity is an independent predictor of 
meningitis and death. CrAg screening for patients with advanced HIV and preemptive treatment is recommended by the World Health Organization, though implementation remains limited. Our objective was to evaluate costs and mortality reduction (lives saved Table 1 shows the values adopted for the procedures and treatments.

Table 1 - Values of procedures, treatments, medications, and tests included in the economic model and other parameters of the model.

\begin{tabular}{|c|c|c|c|c|}
\hline \multicolumn{2}{|l|}{ Procedures/Drugs/Treatment (the reference is no intervention) } & \multicolumn{2}{|c|}{ Costs (U\$S) } & \multirow[b]{2}{*}{ Source } \\
\hline Medicines & Concentration & Unit cost & $\begin{array}{c}\text { Treatment } \\
\text { cost }\end{array}$ & \\
\hline Fluconazole & $150 \mathrm{mg}$ & 0.07 & - & $\begin{array}{l}\text { Brasil. Ministério da } \\
\qquad \text { Saúde }^{12}\end{array}$ \\
\hline Fluconazole & $100 \mathrm{mg}$ & 3.14 & - & $\begin{array}{l}\text { Brasil. Ministério da } \\
\qquad \text { Saúde }^{12}\end{array}$ \\
\hline Daily dosage & $\begin{array}{c}\text { Duration } \\
\text { (weeks) }\end{array}$ & $\begin{array}{l}\text { Daily cost/ } \\
\text { patient }\end{array}$ & $\begin{array}{c}\text { Treatment } \\
\text { cost }\end{array}$ & Source \\
\hline \multicolumn{5}{|c|}{ Preemptive treatment } \\
\hline Fluconazole 800 mg & 2 & 6.56 & 92.00 & $\begin{array}{l}\text { Brasil. Ministério da } \\
\text { Saúde }^{12}\end{array}$ \\
\hline Fluconazole $400 \mathrm{mg}$ & 8 & 3.28 & 184.00 & $\begin{array}{l}\text { Brasil. Ministério da } \\
\text { Saúde }^{12}\end{array}$ \\
\hline \multicolumn{5}{|c|}{ CM treatment } \\
\hline \multicolumn{5}{|c|}{ Induction phase } \\
\hline Mycoses treatment (code 03.03.01.016-9) & 2 & 23.27 & 325.72 & $\begin{array}{l}\text { Brasil. Ministério da } \\
\text { Saúde }{ }^{13}\end{array}$ \\
\hline \multicolumn{5}{|c|}{ Consolidation phase } \\
\hline Fluconazole 600 mg/day & 8 & 0.29 & 17.23 & $\begin{array}{l}\text { Brasil. Ministério da } \\
\qquad \text { Saúde }^{13}\end{array}$ \\
\hline \multicolumn{5}{|c|}{ Maintenance phase } \\
\hline Fluconazole $200 \mathrm{mg}$ & 48 & 6.28 & 2,293.66 & $\begin{array}{l}\text { Brasil. Ministério da } \\
\text { Saúde }{ }^{12}\end{array}$ \\
\hline Tests and culture & Amount & Unit cost & Cost / patient & Source \\
\hline CRAG-LFA & 1 & 6.00 & 6.00 & Brasil $^{14}$ \\
\hline \multicolumn{5}{|l|}{ CRAG-LA } \\
\hline Cryptococcus research - latex (code 4.03.09.05-3) & 1 & 0.36 & 0.36 & $\begin{array}{c}\text { Associação Médica } \\
\text { Brasileira }^{15}\end{array}$ \\
\hline Cryptococcus research - India ink (code 4.03.10.10-0) & 1 & 0.14 & 0.14 & $\begin{array}{l}\text { Associação Médica } \\
\text { Brasileira }^{15} \\
\end{array}$ \\
\hline Culture for fungi identification (code 02.02.08.13-7) & 1 & 0.84 & 0.84 & $\begin{array}{l}\text { Brasil. Ministério da } \\
\text { Saúde }^{13}\end{array}$ \\
\hline Procedures & Amount & Unit cost & Cost / patient & Source \\
\hline $\begin{array}{l}\text { Collection of samples for laboratory examination (code } \\
02.01 .02 .004-1 \text { ) }\end{array}$ & 2 & 0 & 0 & $\begin{array}{l}\text { Brasil. Ministério da } \\
\text { Saúde }^{13}\end{array}$ \\
\hline Specialized medical attention (code 03.01.01.007-2) & 2 & 2.00 & 4.00 & $\begin{array}{l}\text { Brasil. Ministério da } \\
\text { Saúde }^{13}\end{array}$ \\
\hline \multicolumn{5}{|c|}{ Individuals with CRAG-LA test, India's ink (LP) } \\
\hline Lumbar puncture (code 02.01.01.063-1) & 1 & 1.41 & & $\begin{array}{l}\text { Brasil. Ministério da } \\
\text { Saúde }^{13}\end{array}$ \\
\hline \multicolumn{5}{|c|}{ Induction phase } \\
\hline Mycoses treatment (code 03.03.01.016-9) & 2 & 23.27 & 325.72 & $\begin{array}{l}\text { Brasil. Ministério da } \\
\text { Saúde }{ }^{13}\end{array}$ \\
\hline \multicolumn{5}{|c|}{ Consolidation phase } \\
\hline Specialized medical attention (code 03.01.01.007-2) & 2 & 2.00 & 4.00 & $\begin{array}{l}\text { Brasil. Ministério da } \\
\text { Saúde }{ }^{13}\end{array}$ \\
\hline \multicolumn{5}{|c|}{ Maintenance phase } \\
\hline CD4 Lymphocyte count (code 02.02.03.002-4) & 2 & 3.00 & 6.00 & $\begin{array}{l}\text { Brasil. Ministério da } \\
\qquad \text { Saúde }^{13}\end{array}$ \\
\hline $\begin{array}{l}\text { Collection of samples for laboratory examination (code } \\
02.01 .02 .004-1 \text { ) }\end{array}$ & 2 & 0 & 0 & $\begin{array}{l}\text { Brasil. Ministério da } \\
\text { Saúde }^{13}\end{array}$ \\
\hline
\end{tabular}


Table 1 - Values of procedures, treatments, medications, and tests included in the economic model and other parameters of the model. (cont.)

\begin{tabular}{|c|c|c|c|c|}
\hline \multirow{2}{*}{$\begin{array}{l}\text { Procedures/Drugs/Treatment (the reference is no intervention) } \\
\text { Specialized medical attention (code 03.01.01.007-2 -) }\end{array}$} & \multicolumn{4}{|c|}{ Costs (U\$S) } \\
\hline & 3 & 2.00 & 6.00 & $\begin{array}{l}\text { Brasil. Ministério da } \\
\text { Saúde }{ }^{13}\end{array}$ \\
\hline Parameters & Probability (\%) & $\mathrm{Cl}(95 \%)$ & Distribution & Source \\
\hline Percentage of CD4 $\leq 100$ in cryptococcosis & 40 & $30-70$ & & Rajasingham et al. ${ }^{17}$ \\
\hline Percentage CD4 $\leq 200$ cells $/ \mathrm{mm}^{3}$ in cryptococcosis & 60 & $30-70$ & & Rajasingham et al. ${ }^{17}$ \\
\hline Developed CM after preemptive treatment & 14 & & & Meya et al..$^{19}$ \\
\hline Diesd after preemptive treatment & 29.1 & & & Meya et al..$^{19}$ \\
\hline Developed CM after hospital treatment & 8 & $0-20$ & Beta & Meya et al..$^{19}$ \\
\hline CRAG+ among those who developed CM & 33 & $25-41$ & Beta & Rajasingham et al. ${ }^{17}$ \\
\hline CRAG+ among those who developed MC and died & 40 & $34-46$ & Beta & Rajasingham et al. ${ }^{17}$ \\
\hline CM progression in CRAG+ without preemptive treatment & 70 & $56-82$ & Beta & Rajasingham et al. ${ }^{17}$ \\
\hline Survived after hospital treatment & 45 & $38-52$ & Beta & Ramachandran et al. ${ }^{18}$ \\
\hline Developed CM after hospital treatment & 32 & & & Ramachandran et al..$^{18}$ \\
\hline PLHIV CD4 $\leq 200$ cells $/ \mathrm{mm}^{3}$ CRAG + asymptomatic with CM & 2.3 & & & Meya et al..$^{19}$ \\
\hline PIHIV CD4 $\leq 100$ cells $/ \mathrm{mm}^{3}$ CRAG + asymptomatic with CM & 8.04 & $5.8-12.6$ & Beta & $\begin{array}{c}\text { Morawski et al. }{ }^{21} \text {, Meya } \\
\text { et al. } .^{19},\end{array}$ \\
\hline CM mortality (fatality ratio) & $26-63$ & & & Vidal and Boulware ${ }^{8}$ \\
\hline \multicolumn{5}{|c|}{ Utility } \\
\hline Stable with HIV & 0.95 & $0.8-0.98$ & Beta & Miot et al. ${ }^{11}$ \\
\hline CM patient (induction phase) & 0.5 & $0.43-0.58$ & Beta & Miot et al. ${ }^{11}$ \\
\hline Stable with CM (maintenance phase) & 0.8 & $0.68-0.92$ & Beta & Miot et al. ${ }^{11}$ \\
\hline Cryptococcus accuracy tests & $\begin{array}{l}\text { Sensitivity } \\
\text { (\%)/ Cl (\%) }\end{array}$ & & $\begin{array}{l}\text { Specificity } \\
(\%) / \mathrm{CI}(\%)\end{array}$ & Source \\
\hline \multicolumn{5}{|c|}{ Serum } \\
\hline CRAG-LFA & $100(98-100)$ & & $99(97-99.4)$ & Vidal and Boulware $^{8}$ \\
\hline \multicolumn{5}{|l|}{ CSF } \\
\hline CRAG-LA & $97.1(91.9-99.0)$ & & $\begin{array}{l}99.1(93.8- \\
99.9)\end{array}$ & Temfack et al..$^{21}$ \\
\hline India ink & 86.1 & & 97.3 & $\begin{array}{l}\text { Nalintya et al. }{ }^{22}, \\
\text { Boulware et al. }\end{array}$ \\
\hline CSF culture & $95-100$ & & & $\begin{array}{l}\text { Consensus on } \\
\text { cryptococcosis }^{4}\end{array}$ \\
\hline
\end{tabular}

$\mathrm{Cl}=$ confidence interval.

\section{Assumptions}

The parameter assumptions was based on prospective CRAG studies and Brazilian consensus ${ }^{4,17-23}$ with a cohort of HIV-infected patients with CD4 $<100$ cells/uL. Primary outcomes were expected costs, DALYs, and incremental cost-effectiveness ratios (ICERs. CRAG-positive individuals (CRAG+) may be asymptomatic and eligible for the preventive treatment with fluconazole in the model. International studies were used ${ }^{11,17-19,24}$ the prevalence of cryptococcal antigenemia $(\mathrm{CrAg}+$ in the absence of studies on Brazilian population's quality of life for the outcomes described.

The model did not incorporate the ART treatment ${ }^{7}$ after using antifungals, the adverse effects resulting from amphotericin, and intracranial hypertension $(\mathrm{CH})$ as a complication of $\mathrm{CM}$. The use of amphotericin $\mathrm{B}$ deoxycholate $(1 \mathrm{mg} / \mathrm{kg} / \mathrm{week})$ and other drugs to replace fluconazole was not considered.

\section{Economic model}

Figure 1 presents a schematic representation of the transition states for CM screening and treatment, with two residual states where the patient dies or has predominantly negative CM symptoms. Data from the Vidal et al. ${ }^{5}$ a tertiary referral hospital to HIV-infected patients serving the São Paulo State, Brazil. All patients were $>18$ years old without prior cryptococcal meningitis, without clinical suspicion of cryptococcal meningitis, regardless of antiretroviral (ART were used to calibrate the model.

As CM and mortality progression depends on CD4 levels, the target population had two PLHIV subgroups: CD4 $\leq 100$ cells $/ \mathrm{mm}^{3}$ and CD4 $\leq 200$ cells $/ \mathrm{mm}^{3}$. For each 


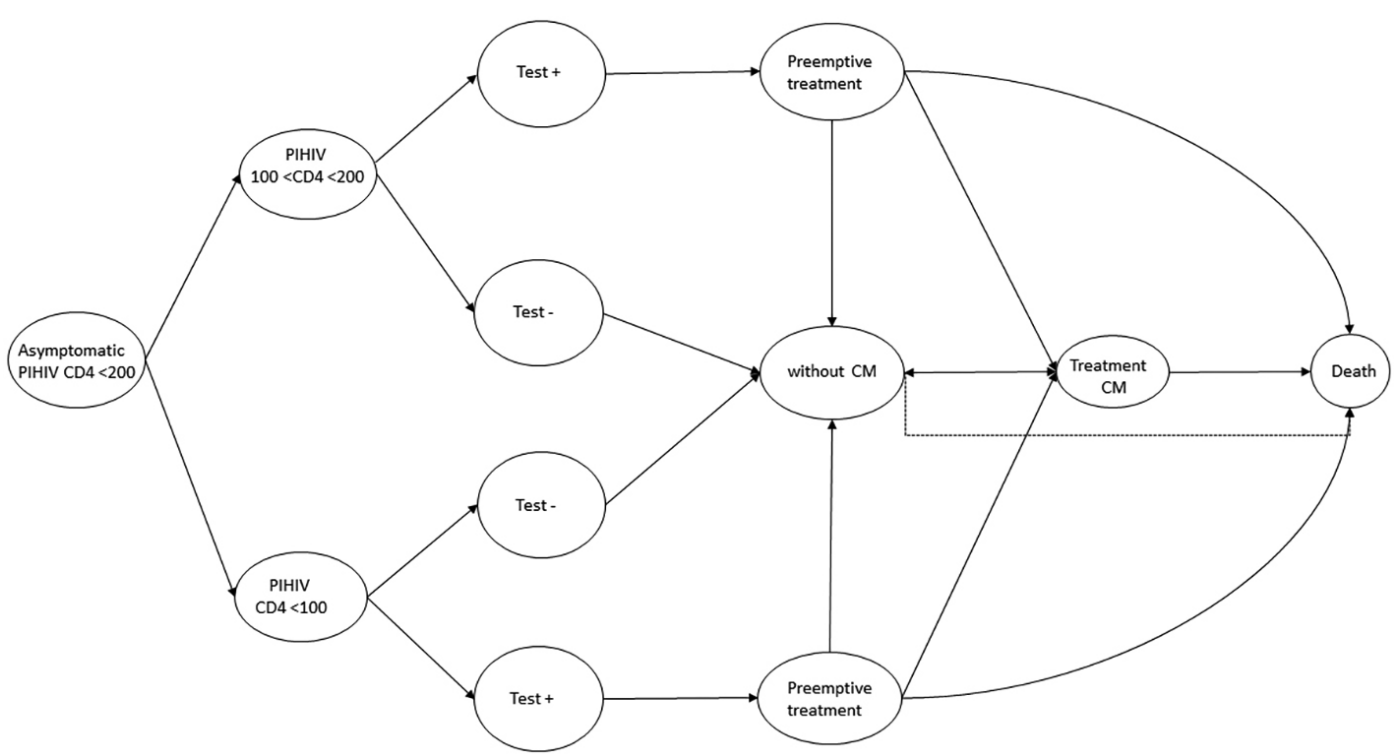

Figure 1 - Schematic model of transition states for the screening of cryptococcal meningitis (CM) in asymptomatic PLHIV with $\leq 200$ cells $/ \mathrm{mm}^{3}$. CM $=$ Cryptococcal meningitis; CRAG $=$ Cryptococcal antigen.

subgroup, after screening, those who were CRAG+ undergo preemptive treatment. After this stage, these individuals may or may not progress to CM. Those who developed CM undergo treatment consisting of induction, consolidation and maintenance. After the end of the treatment, those who did not die progress to a state without CM.

All CRAG-negative individuals, considered without $\mathrm{CM}$, could develop meningitis depending on their true or false negative condition. Those who have undergone preemptive treatment could also progress to a CM status at any time, just as anyone who had finished the in-hospital therapy and may have a relapsed or contracted CM again.

\section{Sensitivity analysis}

Deterministic and probabilistic sensitivities analyzed uncertainties of the model. The discount rate varied from $0 \%$ to $5 \%$, and medical costs were estimated by values found in public purchasing bases.

Patients' utilities and average medical costs changed in a directly proportional manner. Medical costs are related to SUS's services and showed similar results among patients, regardless of the therapeutic alternatives. A scatterplot was constructed in the probabilistic sensitivity analysis indicating the option that was most likely to be cost-effective.

\section{Budget impact}

The budgetary impact analysis employed the demand method $^{25}$. The use of the CRAG-LFA diagnostic test in SUS was simulated for five years to screen for cryptococcus infection in PLHIV with CD4+ $\leq 200$ cells $/ \mathrm{mm}^{3}$. The BIA adopted the SUS perspective ${ }^{25}$. The price of the implemented technology was U\$S 6 per test. The costs to assess the budgetary impact were as follows: screening U\$S 6, preemptive treatment-U\$S 277.8, and meningitis treatment-U\$S 2,644.60 dollars. Table 1 shows the costs of the screening and treatments.

In 2021, the Brazilian population was 212,601,219 inhabitants ${ }^{26}$. The HIV cases considered were the mean number of cases in the period from 2018 to 2020 reported to the Notifiable Diseases Information System (SINAN), declared in the Mortality Information System (SIM), and registered in the Control System for Laboratory Examinations of the National Network of CD4+/CD8+ Lymphocyte Count and HIV Viral Load (SISCEL)/Logistics Control System for Medicines (SICLOM) ${ }^{9}$.

\section{RESULTS}

For the effectiveness measured in years of life, the microsimulation estimated an incremental costeffectiveness ratio (ICER) that is shown in Table 2.

The cost-effectiveness analysis showed that the two tests, CRAG-LA and CRAG-LFA, are cost-effective, a superior performance in comparison with the India ink and the no evaluation scenario.

As the CRAG-LA and CRAG-LFA tests proved to be cost-effective, a deterministic univariate sensitivity analysis evaluated the accuracy of each of the tests, their sensitivities and specificities (Table 3 ). The results for sensitivity showed that both tests are no longer cost-effective for values below 0.975. For specificity, this response occurs for CRAG-LFA 
Table 2 - Incremental cost-effectiveness ratio in years of life and QALY of screening strategies for asymptomatic cryptococcus infections in PLHIV with CD4 $\leq 200$ cells $/ \mathrm{mm}^{3}$.

\begin{tabular}{|c|c|c|c|c|c|c|}
\hline Strategy & Cost (U\$S) & $\Delta$ Cost & $\begin{array}{c}\text { Eff. } \\
\text { (years of life ) }\end{array}$ & $\Delta \mathrm{Eff}$. & $\begin{array}{c}\text { ICER } \\
\text { (U\$S/ years of life) }\end{array}$ & Comments \\
\hline$\overline{\text { CRAG-LA }}$ & 126.65 & 0.000 & 4.718 & 0.000 & 0.000 & \\
\hline CRAG-LFA & 126.90 & 1.255 & 4.721 & 0.003 & 73.37 & \\
\hline India ink & 136.85 & 49.742 & 4.705 & -0.016 & 606.60 & (was superior) \\
\hline \multirow[t]{2}{*}{ No intervention } & 172.27 & 226.873 & 4.603 & -0.118 & 384.57 & (was superior) \\
\hline & Cost (U\$S) ) & $\Delta$ Cost & Eff. (QALY) & $\Delta \mathrm{Eff}$. & ICER (U\$S/QALY) & Comments \\
\hline CRAG-LA & 126.65 & 0.000 & 4.449 & 0.000 & 0.000 & \\
\hline CRAG-LFA & 126.90 & 1.255 & 4.453 & 0.004 & 66.92 & \\
\hline India ink & 136.85 & 49.742 & 4.435 & -0.018 & -553.32 & (was superior) \\
\hline No intervention & 172.27 & 226.873 & 4.323 & -0.129 & -350.79 & (was superior) \\
\hline
\end{tabular}

$\Delta$ = incremental difference; Eff. = effectiveness.

Table 3 - Univariate sensitivity analysis for the cost of the CRAG-LA.

\begin{tabular}{|c|c|c|c|c|c|c|}
\hline Strategy & Cost (U\$S) & Eff. & $\Delta$ Cost & $\Delta \mathrm{Eff}$. & $\begin{array}{c}\text { ICER } \\
\text { (U\$S/ years of life) }\end{array}$ & Comments \\
\hline \multicolumn{7}{|c|}{ Tracking Cost of CRAG-LA U\$S 5.8} \\
\hline CRAG-LA & 126.65 & 4.718 & 0.000 & 0.000 & 0.000 & \\
\hline CRAG-LFA & 126.90 & 4.721 & 1.255 & 0.003 & 73.36 & \\
\hline India ink & 136.85 & 4.705 & 49.742 & -0.016 & -606.60 & (was superior) \\
\hline No intervention & 172.27 & 4.603 & 226.873 & -0.118 & -384.57 & (was superior) \\
\hline \multicolumn{7}{|c|}{ Tracking Cost of CRAG-LA U\$S 6.00} \\
\hline CRAG-LFA & 126.90 & 4.721 & 0.000 & 0.000 & 0.000 & \\
\hline CRAG-LA & 127.03 & 4.718 & 0.645 & -0.003 & -37.70 & (was superior) \\
\hline India' ink & 136.85 & 4.705 & 49.742 & -0.016 & -606.60 & (was superior) \\
\hline No intervention & 172.27 & 4.603 & 226.873 & -0.118 & -384.57 & (was superior) \\
\hline
\end{tabular}

$\Delta=$ incremental difference; Eff $=$ effectiveness. Costs in US dollars considering that 1 U\$S dollar equals 5 reais (the Brazilian current money). Effectiveness in years of life.

above 0.9 and for CRAG-LA with values around 0.99 . The price of CRAG-LA was changed to assess its impact in the result. For the same price as CRAG-LFA, of U\$S 6 per test, the alternative to use CRAG-LA was superior.

The probabilistic sensitivity analysis between CRAG-LFA and CRAG-LA, although pointing to a high agreement between the two tests, indicated the superiority of CRAG-LFA (Figure 2). In approximately $38 \%$ of the cases, this test was superior to the CRAG-LA.

\section{Budget impact}

We would have a total cost for a cohort of 45,000 patients with the hypothesis of all of them treated for meningitis of approximately U\$S 34.8 million dollars for five years without screening. Using the measured demand method and a five-year time horizon, an assumed initial market share of $20 \%$ for CRAG-LFA, with annual increments

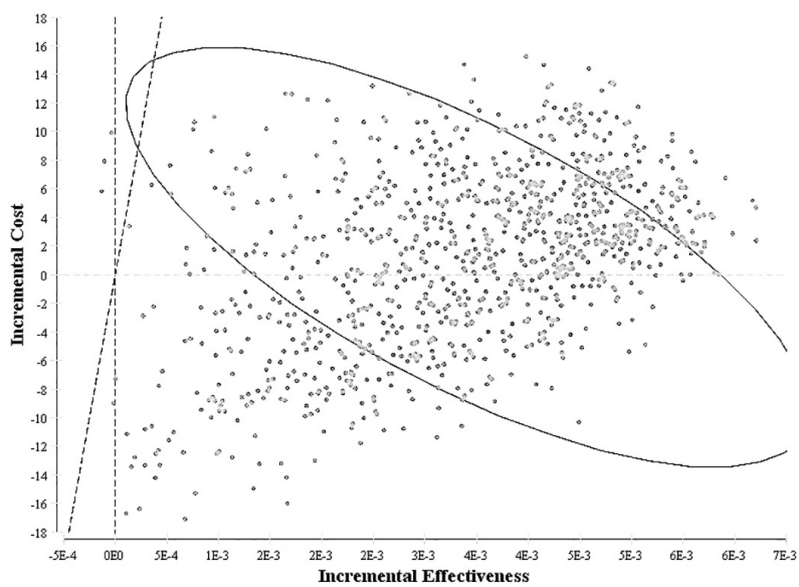

Figure 2 - Probabilistic sensitivity analysis: CRAG-LFA versus CRAG-LA.

of the same amount, reaching $100 \%$ in the fifth year, the estimated budget impact resulting from the incorporation 
of the test would have an additional cost of approximately U\$S 10.5 million dollars. For comparison, the budgetary impact of $100 \%$ adoption of screening for asymptomatic PLHIV CD4 $\leq 200$ cells $/ \mathrm{mm}^{3}$ is a five-year cost savings of U\$S 11 million dollars in this context.

\section{DISCUSSION}

The diagnosis and management of cryptococcosis and its outcomes are structural problems in Brazil ${ }^{1,4,5}$ que fazem parte do complexo C. neoformans. Com o aparecimento da AIDS, houve expressivo aumento na incidência da criptococose. Posteriormente, o uso de antifúngicos profiláticos e a introdução da HAART levaram à redução desta incidência. Objetivamos determinar o perfil epidemiológico da meningite criptocócica no Estado do Rio de Janeiro no período de 1994 a 2004, com base nos dados da Assessoria de Meningite, setor do Centro de Vigilância Epidemiológica da SSE-RJ e, também, avaliar em que medida o perfil epidemiológico disponível no sistema nacional (SINAN. Our study suggests that, for PLHIV with CD4 $\leq 200$ cells $/ \mathrm{mm}^{3}$, the incorporation of CRAG-LFA or CRAG-LA in the patients' screening would be advantageous compared to no screening and the India ink test. Our model projects a reduction in mortality due to CM in PLHIV CRAG+ CD 4200 cells $/ \mathrm{mm}^{3}$ by $15 \%$, while costs for 1,000 patients would decrease by US $\$ 11$ million dollars in five years compared to no screening.

Ramachandran et al. ${ }^{18}$ conducted a study similar to ours in Uganda, Africa. The authors assessed the costs and cost-effectiveness of implementing a CRAG screening for PLHIV in comparison with the usual practice. The CRAG screening was considered highly cost-effective and was associated with an ICER of US\$ 6.14 per avoided DALY compared to no screening. The implementation cost of CRAG screening was of an additional US\$1.52 per person and resulted in a $40 \%$ relative reduction in diseaseassociated mortality. The probabilistic sensitivity analysis showed that the CRAG screening was cost-effective in $100 \%$ of the scenarios. A secondary analysis projected a total cost of US $\$ 651.454$ for the $100 \%$ implementation of the screening in the country, preventing 1,228 deaths compared to no screening.

Another study carried out in Cambodia ${ }^{27}$ one time systematic serum cryptococcal antigen (CRAG evaluated the cost-effectiveness of three alternative strategies for preventing cryptococcal infection in HIV-infected patients. Opportunistic cryptococcal infection is endemic in Cambodia and corresponds to a significant public health burden in PLHIV there and in Brazil. Over a one-year horizon, the systematic CRAG screening (for targeted treatment of positive cases) in patients with $\mathrm{CD} 4 \leq 100$ cells $/ \mathrm{mm}^{3}$ is more cost-effective for preventing cryptococcosis than the systematic primary prophylaxis strategy.

Tenforde et al. ${ }^{28}$ made a cost-effective model of CRAG screening for CRAG+, treatment-naïve patients with CD4 $\leq 100$ cells $/ \mathrm{mm}^{3}$ and CRAG+ CD4 $\leq 100$ cells $/ \mathrm{mm}^{3}$ with previous experience of ART in Botswana. The authors estimated that of 650,000 samples submitted to the CD4 test annually, 16,364 would have CD4 $\leq 100$ cells $/ \mathrm{mm}^{3}$ and would undergo a CRAG test, and $70 \%$ of patients reporting previous experience with ART at the time of screening. CRAG screening and preventive treatment in CD4 treatment-naïve patients with $\leq 100$ cells $/ \mathrm{mm}^{3}$ prevented 20\% of MC-related deaths at the cost of US $\$ 2$ per avoided DALY. The expansion of the preemptive treatment, including patients with previous ART experience and CD4 $\leq$ 100 cells $/ \mathrm{mm}^{3}$, would generated 55 additional cost-avoided deaths with respect to no screening.

The results of the present study deserve to be analyzed carefully. Some limitations are inherent to the modeling process, which can have oversimplified the disease's progression due to differences in real-world circumstances and the use of more than one treatment, disease complications and adverse drug effects. Different sources of international data were the basis for estimating the transition probability values ${ }^{2,8,16,20}$ and we aimed to provide an updated estimate of global incidence of HIV-associated cryptococcal disease. Methods We used 2014 Joint UN Programme on HIV and AIDS estimates of adults (aged $>15$ years. In the sensitivity analysis, these variables did not affect the results. We have also considered that any CM complication would lead to hospitalization or death, which may not be accurate in all cases. The model did not include effects other than meningitis caused by cryptococcal infections and the adverse effects of treatment.

Unit costs calculated from SIGTAP ${ }^{13}$ may be underestimated. Two of the technologies used for comparisons had no prices indicated in the BPS ${ }^{12}$, and the 2016 AMB table was used ${ }^{15}$, which may be out of date. Still, as the CRAG-LFA was superior than the other two tests, these prices have little influence on the result. In this analysis, we assumed equal hospitalization days for patients who underwent screening with any of the technologies. Because of the lower accuracy of a given method, the duration of admission, risk of readmission, and risk of complications that could prolong hospitalization therefore increasing hospital care costs and duration. The cheapest combination corresponding to the use of fluconazole was adopted on the list of $\mathrm{CMED}^{29}$ at a maximum price to the 
consumer instead of the government's purchase price. Finally, the intangible costs of using each technology have not been calculated. The result of the CRAG-LFA test from blood collection can be obtained in 10 minutes. However, CRAG-LA requires a lumbar puncture and a medical follow-up.

\section{CONCLUSION}

An economic evaluation of the Monte Carlo microsimulation estimated the main costs and consequences of the cost-effectiveness analysis and budgetary impact of implementing the CRAG-LFA test for the screening of cryptococcus infection in PLHIV with CD $4+\leq 200$ cells $/ \mathrm{mm}^{3}$ in comparison with the CRAG-LA, the India ink, and no screening as the reference, from the perspective of the Brazilian Unified Health System.

Given the results of this study, the CRAG-LFA and CRAG-LA tests are potentially cost-effective to track cryptococcal infections, preventing mortality related to cryptococcal meningitis in PLHIV with CD4 $\leq 200$ cells $/ \mathrm{mm}^{3}$. India ink and no intervention were inferior strategies. According to the results of the model and the sensitivity analysis, CRAG screening for PLWH with $\mathrm{CD} 4+\leq 200$ cells $/ \mathrm{mm}^{3}$ represents an excellent opportunity to save money with the potential to prevent $\mathrm{CM}$ and reduce the corresponding mortality in Brazil. The BIA showed that for a cohort of 45,000 patients without screening, we would have a total cost of approximately U\$S 34.8 million dollars in five years. The budgetary impact of the $100 \%$ adoption of screening in PLHIV CD4 $\leq 200$ cells $/ \mathrm{mm}^{3}$ and asymptomatic CM infections would save U\$S 11 million dollars in five years.

Finally, a review of epidemiology researches on the consequences of cryptococcal screening in asymptomatic patients highlighted a significant knowledge gap that exist worldwide, especially in Brazil. Now, the paucity of parameters is the main barrier for the development of simulation models that are more compatible with the knowledge accumulated in laboratory practice.

\section{AUTHORS' CONTRIBUTIONS}

CMMV and GBGM participated in the study design; data collection, analysis, interpretation of results and the writing of the manuscript. Both authors read and approved the final version.

\section{CONFLICT OF INTERESTS}

None stated by the authors.

\section{FUNDING}

This project was supported by Department of Management and Incorporation of Technologies and Innovation in Health (DGITIS/SCTIE/MS) and the Pan American Health Organization Brazil - PAHO (grant $\mathrm{N}^{\circ}$ SCON2020-00260).

\section{REFERENCES}

1. World Health Organization. Guidelines for the diagnosis, prevention and management of cryptococcal disease in HIV-infected adults, adolescents and children: supplement to the 2016 consolidated guidelines on the use of antiretroviral drugs for treating and preventing HIV infection. Geneva: WHO; 2018. [cited 2021 Jun 22]. Available from: http://apps.who.int/iris/bitstream/han dle/10665/260399/9789241550277-eng.pdf;jsessionid=3DD4 7D6B4F06AFA32280E2048900A316? sequence $=1$

2. Rajasingham R, Smith RM, Park BJ, Jarvis JN, Govender NP, Chiller TM, et al. Global burden of disease of HIV-associated cryptococcal meningitis: an updated analysis. Lancet Infect Dis. 2017; 17:873-81.

3. Pappalardo MC, Melhem MS. Cryptococcosis: a review of the Brazilian experience for the disease. Rev Inst Med Trop Sao Paulo. 2003;45:299-305.

4. Consenso em criptococose: 2008. Rev Soc Bras Med Trop. 2008;41:524-44.

5. Vidal JE, Toniolo C, Paulino A, Colombo A, dos Anjos Martins M, da Silva Meira C, et al. Asymptomatic cryptococcal antigen prevalence detected by lateral flow assay in hospitalised HIVinfected patients in São Paulo, Brazil. Trop Med Int Heal. 2016;21:1539-44.

6. Merry M, Boulware DR. Cryptococcal meningitis treatment strategies affected by the explosive cost of flucytosine in the United States: a cost-effectiveness analysis. Clin Infect Dis. 2016;62:1564-8.

7. Brasil. Ministério da Saúde. Secretaria de Vigilância em Saúde. Departamento de Vigilância, Prevenção e Controle das Infecções Sexualmente Transmissíveis, do HIV/Aids e das Hepatites Virais. Protocolo clínico e diretrizes terapêuticas para manejo da infecção pelo HIV em adultos. Brasília: Ministério da Saúde; 2018. [cited 2021 Jun 22]. Available from: http://www.aids.gov. br/pt-br/pub/2013/protocolo-clinico-e-diretrizes-terapeuticaspara-manejo-da-infeccao-pelo-hiv-em-adultos

8. Vidal JE, Boulware DR. Lateral flow assay for cryptococcal antigen: an important advance to improve the continuum of HIV care and reduce cryptococcal meningitis-related mortality. Rev Inst Med Trop Sao Paulo. 2015;57 Suppl 19:38-45.

9. Brasil. Ministério da Saúde. Indicadores e dados básicos do HIV/ AIDS nos municípios brasileiros. [cited 2021 Jun 22]. Available from: http://indicadores.aids.gov.br/ 
10. Brasil. Ministério da Saúde. Secretaria de Ciência, Tecnologia e Insumos Estratégicos. Departamento de Ciência e Tecnologia Diretrizes metodológicas : diretriz de avaliação econômica. $2^{a}$ ed. Brasília: Ministério da Saúde; 2014. [cited 2021 Jun 22]. Available from: https://bvsms.saude.gov.br/bvs/publicacoes/ diretrizes_metodologicas_diretriz_avaliacao_economica.pdf

11. Miot J, Leong T, Takuva S, Parrish A, Dawood H. Costeffectiveness analysis of flucytosine as induction therapy in the treatment of cryptococcal meningitis in HIV-infected adults in South Africa. BMC Health Serv Res. 2020 In Press.

12. Brasil. Ministério da Saúde. Banco de preços em saúde. [cited 2021 Jun 22]. Available from: http://bps.saude.gov.br/login.jsf

13. Brasil. Ministério da Saúde. SIGTAP: Sistema de Gerenciamento da Tabela de Procedimentos, Medicamentos e OPM do SUS [cited 2021 Jun 22]. Available from: http://sigtap.datasus.gov. br/tabela-unificada/app/sec/inicio.jsp

14. Brasil. Ministério da Saúde. Secretaria de Ciência, Tecnologia, Inovação e Insumos Estratégicos em Saúde. Coordenação de Monitoramento e Avaliação de Tecnologias em Saúde. Teste diagnóstico, point of care, de Cryptococcal Antigen Lateral Flow Assay (CRAG-LFA) para detecção de infecção por Cryptococcus e diagnóstico de meningite criptocócica em pessoas vivendo com o vírus da imunodeficiência humana (PVHIV). Brasília: Ministério da Saúde; 2021. [cited 2021 Jun 22]. Available from: http://www.conitec.gov.br/images/ Relatorios/2021/20210611_Relatorio_615_CragLFA_ meningite-criptococica_Final.pdf

15. Associação Médica Brasileira. CBHPM-2016 : Classificação Brasileira Hierarquizada de Procedimentos Médicos. Barueri: Manole; São Paulo: Associação Médica Brasileira; 2016. [cited 2021 Jun 22]. Available from: https://www.cbo.net.br/novo/ publicacoes/CBHPM_2016.pdf

16. Lofgren SM, Nalintya E, Meya DB, Boulware DR, Rajasingham R. A qualitative evaluation of an implementation study for cryptococcal antigen screening and treatment in Uganda Medicine (Baltimore). 2018;97:e11722.

17. Rajasingham R, Meya DB, Greene GS, Jordan A, Nakawuka M, Chiller TM, et al. Evaluation of a national cryptococcal antigen screening program for HIV-infected patients in Uganda: a cost-effectiveness modeling analysis. PLoS One. 2019;14:e210105.

18. Ramachandran A, Manabe Y, Rajasingham R, Shah M. Costeffectiveness of CRAG-LFA screening for cryptococcal meningitis among people living with HIV in Uganda. BMC Infect Dis. 2017; 17:225

19. Meya DB, Manabe YC, Castelnuovo B, Cook BA, Elbireer AM,

Kambugu A, et al. Cost-effectiveness of serum cryptococcal antigen screening to prevent deaths among HIV-infected persons with a CD4 + cell count $\leq 100 \mathrm{Cells} / \mu \mathrm{L}$ who start HIV therapy in resource-limited settings. Clin Infect Dis. 2010;51:448-55.
20. Longley N, Jarvis JN, Meintjes G, Boulle A, Cross A, Kelly N, et al. Cryptococcal antigen screening in patients initiating ART in South Africa: a prospective cohort study. Clin Infect Dis. 2016;62:581-7.

21. Temfack E, Rim JJ, Spijker R, Loyse A, Chiller T, Pappas PG, et al. Cryptococcal antigen in serum and cerebrospinal fluid for detecting cryptococcal meningitis in adults living with human immunodeficiency virus: systematic review and metaanalysis of diagnostic test accuracy studies. Clin Infect Dis. 2021;72:1268-78.

22. Nalintya E, Kiggundu R, Meya D. Evolution of cryptococcal antigen testing: what is new? Curr Fungal Infect Rep. 2016;10:62-7.

23. Boulware DR, Rolfes MA, Rajasingham R, von Hohenberg M, Qin Z, Taseera K, et al. Multisite validation of cryptococcal antigen lateral flow assay and quantification by laser thermal contrast. Emerg Infect Dis. 2014;20:45-53.

24. Morawski BM, Boulware DR, Nalintya E, Kiragga A, Kazooza F, Rajasingham R, et al. Pre-ART cryptococcal antigen titer associated with preemptive fluconazole failure. In: Conference on Retroviruses and Opportunistic Infections; 2016 Feb 22-25; Boston, Massachusetts. [cited 2021 Jun 22]. Available from: https://www.croiconference.org/abstract/pre-art-cryptococcalantigen-titer-associated-preemptive-fluconazole-failure/

25. Brasil. Ministério da Saúde. Secretaria de Ciência, Tecnologia e Insumos Estratégicos. Departamento de Ciência e Tecnologia. Diretrizes metodológicas: análise de impacto orçamentário : manual para o sistema de saúde do Brasil. Brasília: Ministério da Saúde; 2012. [cited 2021 Jun 22]. Available from: https://bvsms.saude.gov.br/bvs/publicacoes/diretrizes_ metodologicas_analise_impacto.pdf

26. Instituto Brasileiro de Geografia e Estatística. Projeção da população do Brasil e das unidades da federação. [cited 2021 Jun 22]. Available from: https://www.ibge.gov.br/apps/ populacao/projecao/index.html?utm_source=portal\&utm medium=popclock\&utm_campaign=novo_popclock

27. Micol R, Tajahmady A, Lortholary O, Balkan S, Quillet C, Dousset JP, et al. Cost-effectiveness of primary prophylaxis of AIDS associated cryptococcosis in Cambodia. PLoS One. 2010;5:e13856

28. Tenforde MW, Muthoga C, Callaghan A, Ponatshego P, Ngidi J, Mine $\mathrm{M}$, et al. Cost-effectiveness of reflex laboratory-based cryptococcal antigen screening for the prevention and treatment of cryptococcal meningitis in Botswana. Wellcome Open Res. 2020;4:144.

29. Brasil. Agência Nacional de Vigilância Sanitária. Câmara de Regulação do Mercado de Medicamentos. Preços máximos de medicamentos por princípio ativo. Brasília; 2020. [cited 2021 Jun 22]. Available from: https://www.gov.br/anvisa/ pt-br/assuntos/medicamentos/cmed/precos/anos-anteriores/ arquivos/4910json-file-1 